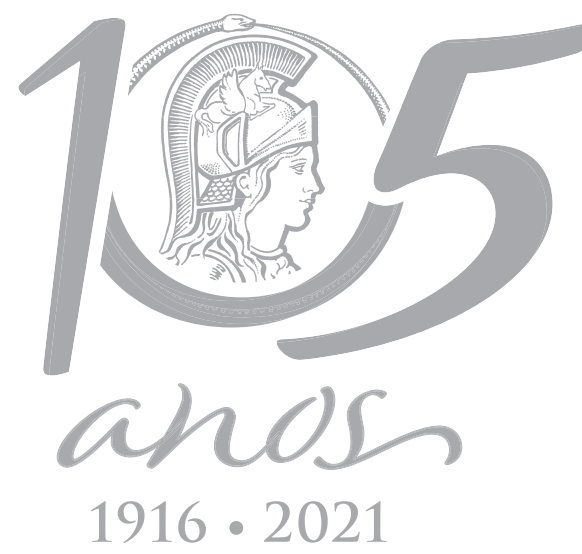

\title{
The concept of monument in the map of 1942. Ibagué, Colombia
}

\author{
ANDRÉS E. FRANCEL-DELGADO \& CLAUDIA URIBE-KAFFURE
}

\begin{abstract}
The beginning of the concept of architectural monument in Colombia is in the laws from the late XIX century and early XX century. We recompose the international context through the technic of aero photography, used by the Military Geographical Institute during the Second World War and the consequent tensions between U.S. and the powerful nations of the axis in relation to Colombia and Brazil in Latin America. The Liberal Party emerges like an ideology that tried to reorganise the country through the establishment of education and control the soil. This party negotiated a pact to stop the Colombian-Peruvian war 1932-1933, and signed the Roerich Pact in 1935 to protect the monuments. Therefore, the 1942 plan is the end of a process of mapping the national territory and the generation of criteria about cultural heritage in the first half of XX century, and the base to study how it affected the protection of architectural monuments up to date.
\end{abstract}

Key words: Aero photography, architectural heritage, mapping, monument, Military Geographical Institute.

\section{INTRODUCTION}

Maps are political instruments because they have a porpoise derived from the interest of a person, community or institution (Díaz Ángel et al. 2010). Maps also are testimonies of the transformation of the information between the physic and perceived reality (Schimalski 2001, Ratajski 1977). That means that the reality changes in relation to the modification of thought in every moment of the history. Because of that, the map is a cognitive space for the production of thought about the space (Girardi 2009).

The study of maps implies to analyse its artistic graphic technic, and its political administrative purposes. Consequently, it is necessary to search the motifs to create a plan for a city and find out the aspects to rebuild this mentality. Because of that, the analysis of the 1942 map starts in the recognition of similarities with other maps in a determined context: the similarities in technic and graphic conventions, and the recognition of the cultural heritage.

\section{MATERIALS AND METHODS}

This is a historical researching, performed by diverse components. The firs one is the theoretical horizon under the concept of cartology, defined as "the study of expression and transformation of physical information through a map" (Schimalski 2001). The interpretation of the maps derived from a circuit of observation, representation and interpretation of the information, according to the diagram of Ratajski (1977) [Figure 1].

The second component is the documentalphilological approach that consists on the search of documents to allow the reconstruction of the historical moment for the creation of 


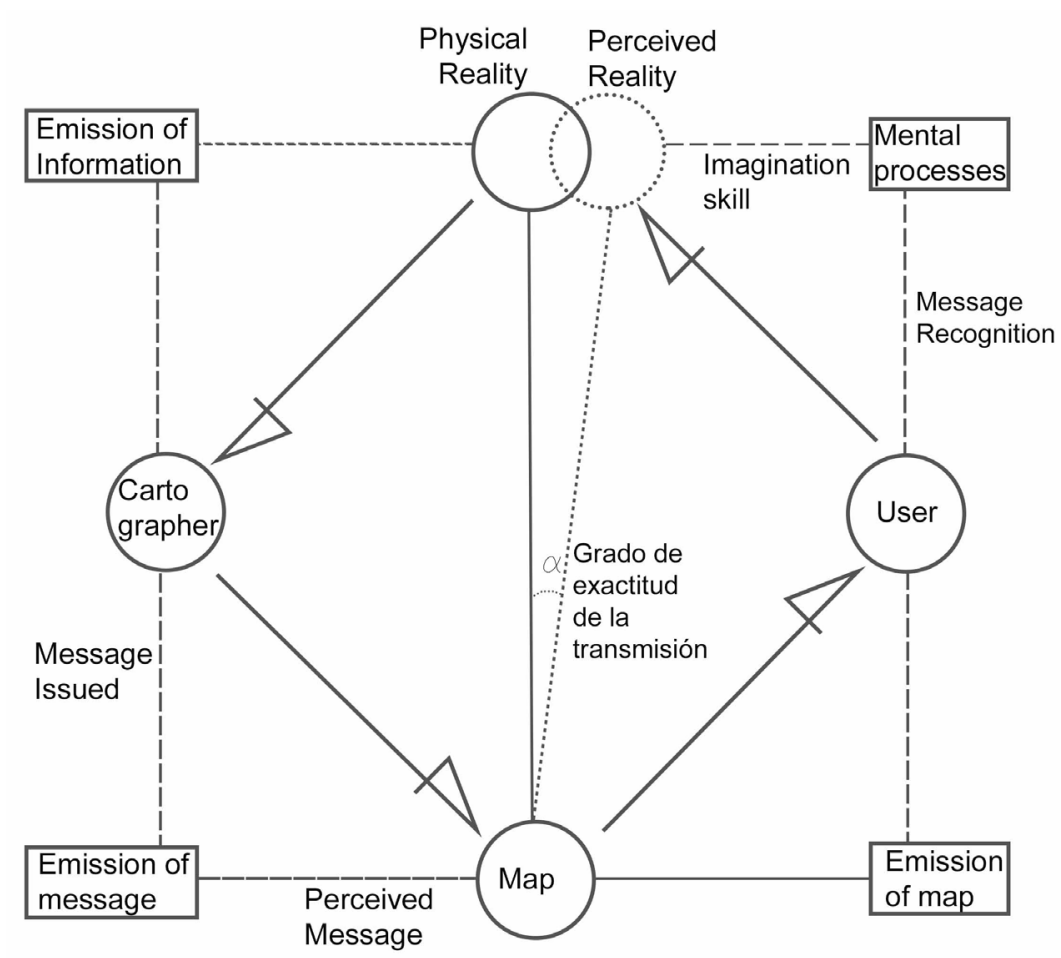
Figure 1. Ratajski
model of cartographic
communication.

the map. Mainly, the links between the maps, its cartographer, the institutional power and the law as a vehicle to canalize the intentions. Through this component, emerged the study of the concept of monument in the Colombian laws in the late XIX century and early XX century, and the action of the Military Geographic Institute to elaborate the map, commissioned by President Alfonso López Pumarejo, who signed the Roerich Pact in 1935 and his political liberal environment.

The third component is the historicalartistic approach, based on the observation and comparison of maps to identify ideas and underlying concepts (Moreno 2014). The documents collected in the second component pass through a comparison to find out similarities and divergences that permit to situate the graphic piece in a specific context.

The fourth component is the identification of the buildings in the 1942 map and their classifications as monument, important building, National or Local Heritage Site, if these remain and have a patrimonial declaratory today. The fluctuation of these buildings attends to the controversy between the interest of the construction industry to densify the old lots in the downtown and the disposition of the local governments to defend a concept of public interest.

\section{RESULTS}

The concept of monument present in the Ibague map of 1942, let us to identify it as graphic consequence of war. Corresponds to an international interest for protecting the monuments from the destruction derived from Second World War, and the tensions between USA and Germany to control the continental airspace. In a regional level, represents the eagerness to map out the entire national territory to clarify the frontiers because of the Peruvian-Colombian War and its solution through the Roerich Pact. In a national level, it is a material evidence of the 
policies of the Liberal Party to reorganize the country through an inventory of land property, after 44 years of conservative hegemony. In a local level, the map means the incorporation of an undefined concept of monument to protect the symbols that is controversial still now.

In the technical aspects, we found three linked maps to Ibague 1942 those are the Bogotá plan of 1938, Lima 1935 and São Paulo 1930. These used the aero photographic restitution, but have not the concept of monument included in the conventions. This concept is in the maps of Lima 1904 and, 1924. In 1904 are four monuments like commemorative artworks. In 1924 map, the conventions show a group formed by "Monuments, Public and Notable Buildings \& city Squares". Although, these maps from 1904 and 1924 have not the aero photographic restitution as the technical base (Doering 1983). Therefore, the confluence of technic and the associated concept of monument is relevant only in Bogotá 1938 and São Paulo 1930. Both cities and both countries have similar elements as the developing of the aero photographical mapping of the territory by alliances with Germany and Italy, two nations that formed the axis in the Second World War and represented a threatening for U.S. control of the continent.

The concept of monument only find clarity in Colombia in Law 5 of September 6 of 1940. Before, the laws are unclear although represent the interest for protecting the national heritage. Even, urban plans as Ibague Future 1935 avoid the treatment of this concept and consider the aesthetics and heritage as an antipathetic and pedantic subject. Consequently, the study of 1942 map of Ibague let to identify 1940 as a fundamental year to interpret and determinate how the concept of monument become an interaction between laws, cartography and the construction of governmental buildings.

\section{DISCUSSION}

The map has a grid of 500 meters. The centre of the city is in the intersection of the third squares, in a sense of reading left to right and up to down. In this square is the most of the monuments, in black filled shapes. The quadrant of fourth squares shows the zone of expansion during the early XX Century and the railroad station is in its intersection. The right part of the map shows the zone of expansion in 1940's with lots still empty [Figure 2].

The first step to analyse the contents of the map toward the concept of monument was the identification of the buildings black filled in the map with their names in 1940. To do it, we used the recent scientific literature about the architecture and urbanism of the city (Alvarez \& Francel 2018, Francel 2017a, b, c, d, Francel \& Ojeda 2016a, b, c, d, Francel 2015a, b, c, d, Cifuentes Segovia 2015). The interviews with the local awarded architect Carlos Martínez Silva, who lived nearly that time, complemented the information gaps in the scientific literature [Figure 3].

We determinate if these buildings remain nowadays, if they have heritage register and if there are new buildings that replaced them. We classified them like State Heritage Site (SHS), National Heritage Site (NHS), because of their legal treatment. In this sense, the Ministry of Culture declares National Heritage, and State Council of Culture declares Local Heritage. In consequence, national or state government provides the finances to support them [Table I].

From 21 buildings classified as monuments in 1942, eight remain, and five of these have a Heritage Register. That means that only a fourth part of those buildings (23\%) remain and are under a legal protection, three of them remain without any legal protection, and the rest were demolished. Six new buildings obtained 


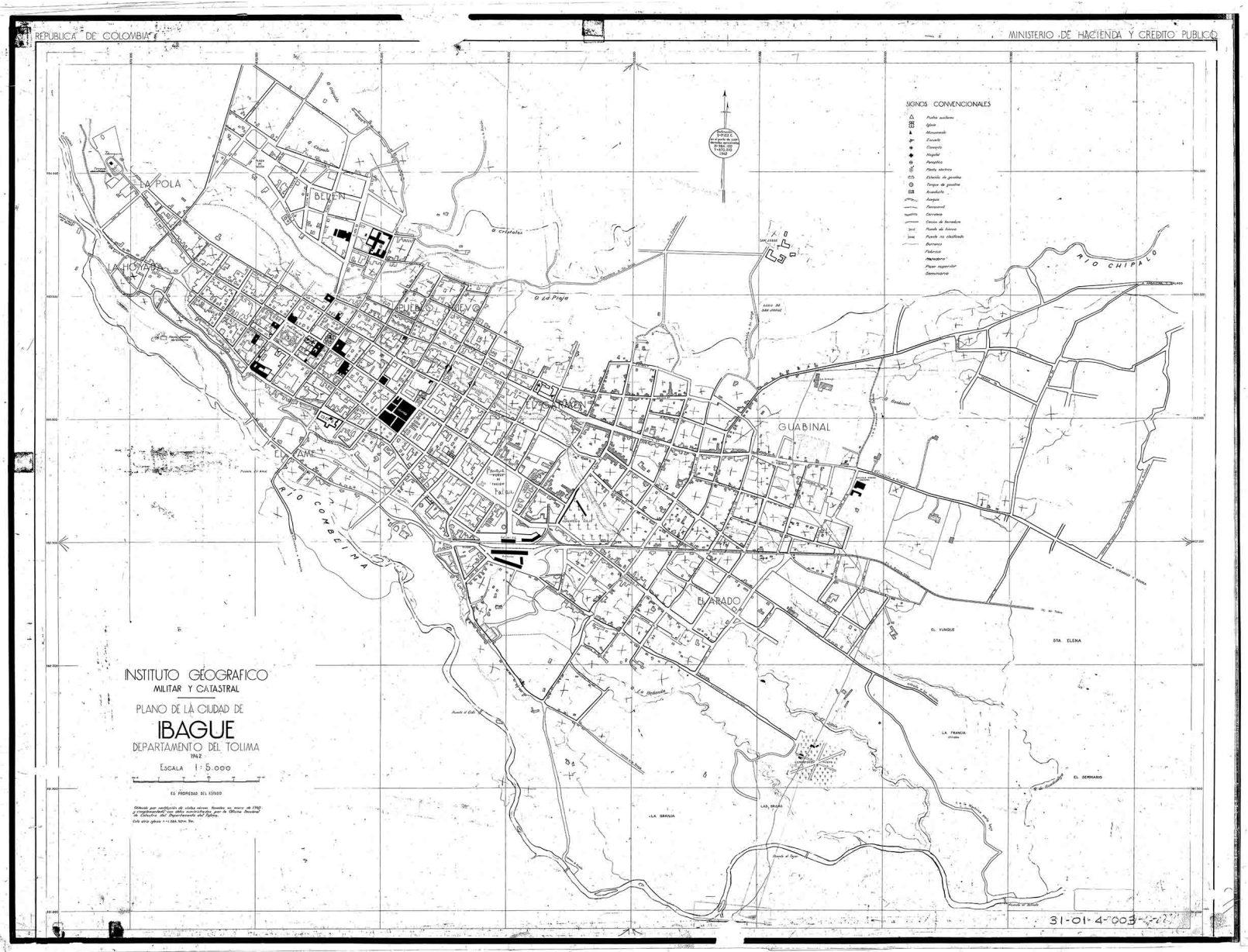

Figure 2. Map of Ibague City 1942. Obtained by restitution of aerial views taken in January 1940 and complemented with data supplied by Cadastre Sectional Office of Department of Tolima. Geographical and Military Cadastral Institute (1942).

a Heritage Register, but destroying their predecessors. In this sense, the government has been the main destructor of the heritage in order to create new public buildings and this shows a lack of clarity about how to manage and protect the heritage sites.

It is important to stand out that an engineering work as the water tanks in La Pola sector was included in the list. It is linked to the development of the new aqueduct recommended in the Urbanistic plan Ibague Future 1935, and shows the relevance of the new works for the advance of the city. The Society of Engineering hired for this job, highlighted the importance of the modernization of the aqueduct, as the base of the projection of the city into the new dynamics of the second half of the XX century (Francel 2017b). This implies the consideration of a monument as a useful work for the future and the impact of the new in the early XX century.

There are in the map bold contours for important buildings with indications about their civil use, as hospital, churches, convent, and powerhouse. Some of them are heritage today and let us to identify a distinction between monuments and important buildings in 1940. These are two unclear concepts because there are not local or national convincing sources to interpret it accurately. Consequently, we 


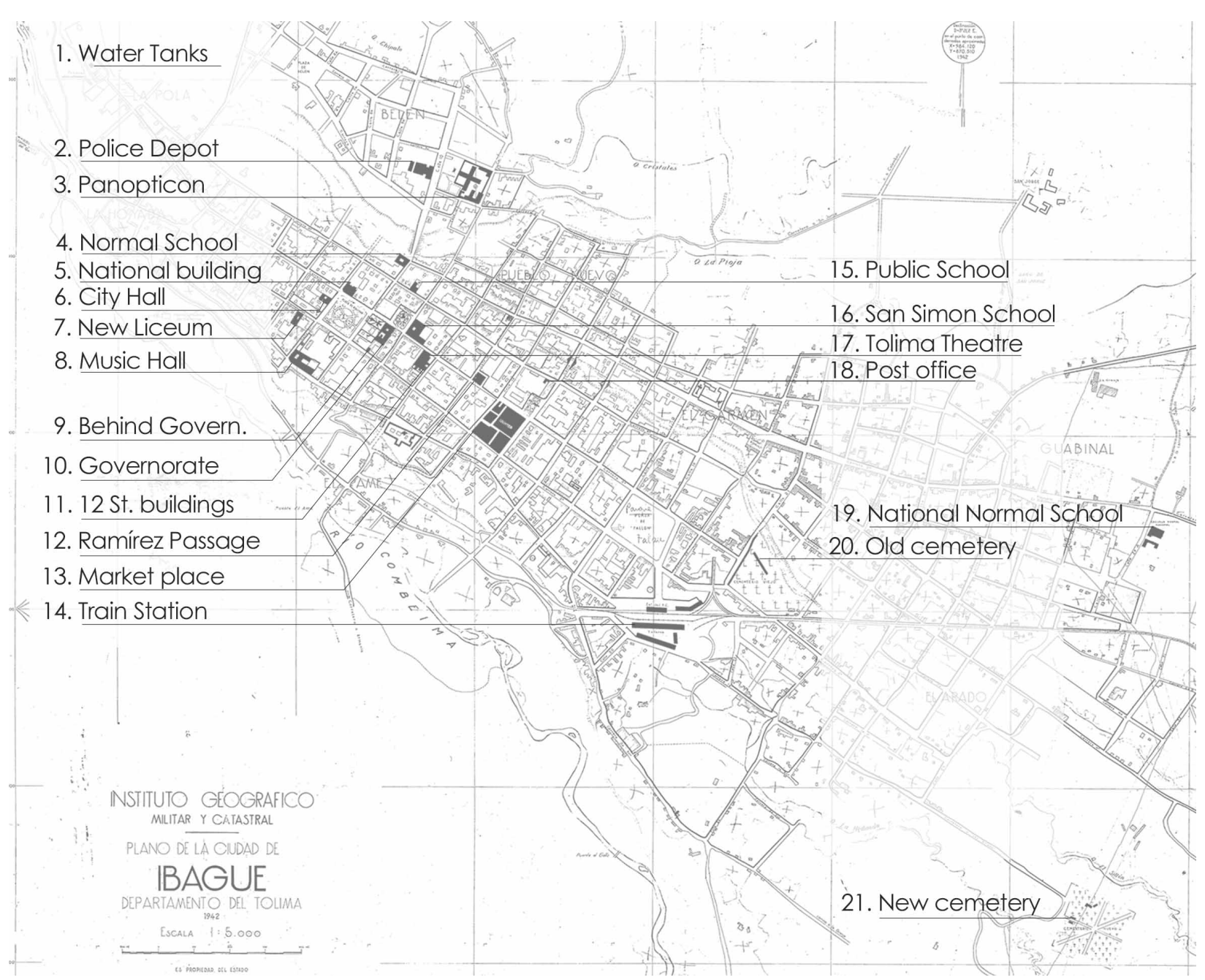

Figure 3. Monuments in 1942 with solid fill.

have a classification of two levels of hierarchy: monuments in the first level and important buildings in the second level. The next thematic section will explore those concepts [Figure 4] [Table II].

The final step to identify the characteristic of the monuments and important buildings in 1942 Ibague map, consisted of contrast it with the current norms on the declarations of patrimony. Today, there are 35 State Heritage Sites and 4 National Heritage Sites in Ibague [Table III, Table IV].

The destruction of the local and national heritage sites has been systematic because the conservation of the monuments represents an obstacle to develop the city. The generation of laws to protect these sites, depend on the disposition of the local governments to make effective the norms. However, constantly courts derogate the norms and there only remain a history of decrees with temporal effects (Sociedad Colombiana de Arquitectos - Regional Tolima 2002, Francel 2017c). Even today, there is a demand for derogating the most recent law of February 2018 to protect the local heritage sites (El Nuevo Día 2019).

\section{The concept of monument in Colombia}

The first approach to the monuments is in the Law 18 of 24 April 1865, which creates the 
National Institute of Sciences and Arts with a gallery of "Fatherland monuments" (Congress of the States of Colombia 1865). The law did not define the concept of monument, but established profiles for every director of the dependencies, as a librarian, an inspector of the museum, a professor of natural history, and a chief of painting gallery. Nevertheless, there is nothing about the management of Fatherland monuments gallery, created in that national Law. An important gap that shows the intention to protect the buildings through unclear concepts.

In 1918, the Congress of Colombia issued the Law 48 to create the National Direction of Fine Arts, in order to inspect, preserve, adapt, transform, visit, improve and authorize interventions according to the "principles of art" (Congress of Colombia 1918). In that document, the buildings and monuments from the colonial and pre-Columbian period became "material of Fatherland History" and emerges an uncertain differentiation between building and monument and the consideration of the colonial architecture as a monument itself.

The Law 103 of 1931 promotes the conservation of the archaeological monuments of San Augustin, and declares as "public interest" the "monuments and archaeological objects" all over the country (Congress of Colombia 1931). Again, there is evident the concept of monument and its differentiation to archaeological objects without clear arguments to identify buildings as monuments.

In the same way of local monuments in San Augustin, it is possible to find legal operations in Cartagena, as Law 32 of 1924 (conservation and enhancement of the monuments of Cartagena), and Law 11 of 1932 (Commission on Historic Monuments and Tourism) (Unesco 2019). Despite of this local impact, it is evident an increasing interest for the monuments in the middle of a dual concept of the monument as a commemorative element, or buildings that are valued for their relationship with history (Barbosa 2012).

However, a key moment is in the Law 5 of September 6 of 1940, which declares "national monuments, of public utility, all those buildings that by their antiquity and architectural beauty deserve to be conserved as national heritage" (Congress of Colombia 1940). This law let us to understand the two main concepts to declare a building as a national monument, first their antiquity and second architectural beauty. The antiquity explains the chronological order in heritage protection laws, first the pre-Columbian works, later the colonial historical centres, and, from the 1940 law, historicist or republican buildings star to be part of that past. The architectural beauty remains as an undefined concept because it depends on the agreements between experts, generally academics related to the power. That explains the inclusion of the Female Normal School as a monument in the map of Ibague 1942, the same year of its construction.

Other important aspect about the date of the map is its elaboration from aerial views from January 1940. In September 6 of 1940, the Congress of Colombia published the law of national monuments and in October 14, Ibague celebrated its 390 foundation-day. The map was a perfect present for the city foundation-day, usual in cities like Bogotá, as will be shown in the next thematic section. However, the delaying of two years to publish the map, direct us to the wish of making a graphic piece for the 450 centenary of the European colonization of the Americas 1492-1942, commemorated as Columbus Day in October 12, two days before of the city foundation day. To explore these dimensions, the next thematic section addresses to identify the technic used. 
Table I. List of monuments in the Ibague map of 1942.

\begin{tabular}{|c|c|c|c|}
\hline 1942 Monument & Remain & Heritage Register & New Building \\
\hline 1. Water tanks in La Pola & Yes & No & \\
\hline 2. Police Depot (EFAC) & Yes & SHS & \\
\hline 3. Panopticon & Yes & NHS & \\
\hline 4. New Lyceum & Yes & No & \\
\hline 5. Alberto Castilla Music hall & Yes & NHS & \\
\hline 6. City hall & No & & SHS (Same use) \\
\hline 7. National building & Yes & NHS & \\
\hline 8. Female Normal School & No & & \\
\hline 9. House behind Governorate (2nd Av.) & No & & SHS (Governorate) \\
\hline 10. Governorate & No & & NHS (same use) \\
\hline 11. Public School (K4 - St 10-11) & No & & SHS (Social Circle) \\
\hline 12. San Simon school & No & & SHS (Bank) \\
\hline 13. Tolima Theatre & No & & NHS (same use) \\
\hline 14. 12 Street buildings & No & & \\
\hline 15. Ramirez passage & No & & \\
\hline 16. Market Place 14 Street & No & & \\
\hline 17. Post office & No & & \\
\hline 18. Train Station & No & & \\
\hline 19. Old Cemetery & No & & \\
\hline 20. New Cemetery & Yes & SHS & \\
\hline 21. National Normal school & Yes & No & \\
\hline
\end{tabular}

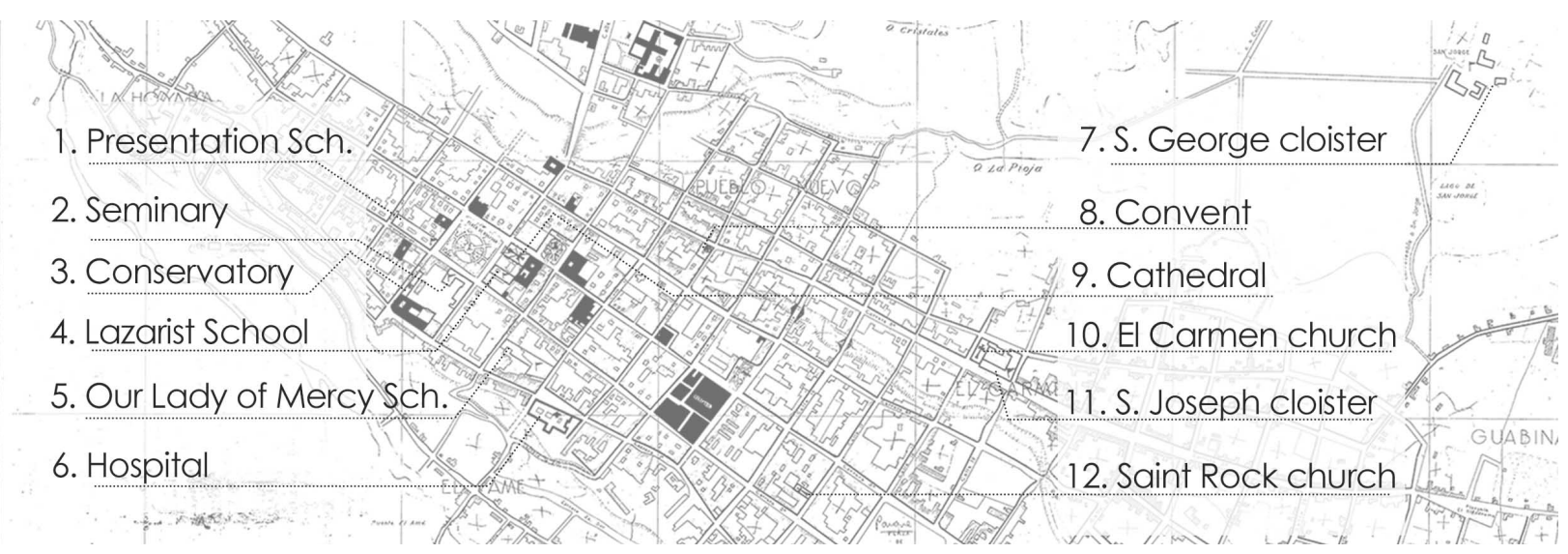

Figure 4. Important buildings in 1942. 
Table II. Important buildings in 1942.

\begin{tabular}{|c|c|c|c|}
\hline 1942 Important Building & Remain & Heritage Register & New Building \\
\hline 1. Presentation school & Yes & SHS & \\
\hline 2. Conservatory & Yes & NHS & \\
\hline 3. Seminary & No & & SHS (other use) \\
\hline 4. Cathedral & Yes & SHS & \\
\hline 5. Lazarist school & No & & \\
\hline 6. Our Lady of Mercy School (St 11-12 Av 1-2) & No & & \\
\hline 7. Hospital & No & & \\
\hline 8. Convent (13St-5thAv) & No & & \\
\hline 9. Saint Rock church & Yes & SHS & \\
\hline 10. Powerhouse & No & & \\
\hline 11. Architectural complex El Carmen/San Joseph & Yes & SHS & \\
\hline 12. San Jorge cloister & Yes & NHS & \\
\hline
\end{tabular}

\section{Law and maps}

Regardless of these laws before 1940, an approaching to the maps of that time reveals an absence of the concept of monument. To establish that affirmation, we used the Cartographic Atlas of Bogotá (Cuéllar Sánchez \& Mejía Pavony 2007), where the national laws have the fastest impact. The result is that the maps from the colonial time up to 1942 stand out the main buildings of the city in general, by zones or neighbourhoods, but does not include the concept of monument in any case.

Attending to the issued of laws in 1918 and 1931, it is possible to affirm that these did not affect directly the contents of maps in the sense that these have not the concept of monument. Conversely, after 1931 the list of main buildings is less frequent, and disappear by 1935. The number of monuments in the maps of Bogotá from 1894 up to 1933 varies due to the inclusion of squares and commercial buildings, because some merchants made maps to promote their stores [Table V].

Complementarily, the maps do not show details inside the squares as lot division and have not included the concept of monument. The map of Bogotá 1935 has not a list of buildings, but shows graphic patterns for "Temples and important public buildings" (p. 89), although schematic and does not define internal contours for green spaces or limits of properties or buildings like the Ibague 1942 does. 
Table III. State Heritage Buildings compared 2018-1942.

\begin{tabular}{|c|c|c|c|c|c|}
\hline & \multirow{2}{*}{2018 State Heritage Building } & \multicolumn{2}{|c|}{1942} & \multicolumn{2}{|c|}{2018} \\
\hline & & Monument & Important & New & Added \\
\hline 1 & National Building & Monument & & & \\
\hline 2 & Cathedral & & Important & & \\
\hline 3 & Architectural complex El Carmen/San Joseph & & Important & & \\
\hline 4 & Saint Roch church & & Important & & \\
\hline 5 & City Hall & Monument & & & \\
\hline 6 & College La Presentación & & Important & & \\
\hline 7 & Seminary & & Important & New & \\
\hline 8 & Governorate & Monument & & New & \\
\hline 9 & Tolimense School & & Important & & \\
\hline 10 & Social Circle & Monument & & New & \\
\hline 11 & Apartments of the Curia & Monument & & New & \\
\hline 12 & Municipal council (Police Depot) - EFAC & Monument & & & \\
\hline 13 & Market place Street 14 & Monument & & New & \\
\hline 14 & Market place Street 21 & & & & Added \\
\hline 15 & Market place Street 28 & & & & Added \\
\hline 16 & Saint Boniface Cemetery & Monument & & & \\
\hline 17 & Saint Simon School and church & & & New & \\
\hline 18 & Palace of Justice & Monument & & New & \\
\hline 19 & Urrutia House & & & & Added \\
\hline 20 & Archiepiscopal house & & & & Added \\
\hline 21 & Coffee Bank building & & & & Added \\
\hline 22 & Xavierian University House & & & & Added \\
\hline 23 & Bank of Republic & Monument & & New & \\
\hline 24 & Sixth Brigade building & & & & Added \\
\hline 25 & Café Paris & & & & Added \\
\hline 26 & CAM Market place & & & & Added \\
\hline 27 & National Lyceum & & & & Added \\
\hline 28 & Minerva Clinic & & & & Added \\
\hline 29 & House of the Pulecio Melendro family & & & & Added \\
\hline 30 & Ganadero Bank & & & & Added \\
\hline 31 & House of Hacienda El Vergel & & & & Added \\
\hline 32 & House of Melendro Serna family & & & & Added \\
\hline 33 & House of Santofimio Botero family & & & & Added \\
\hline 34 & Mary Help of Christians church & & & & Added \\
\hline 35 & Saint Jude church & & & & Added \\
\hline
\end{tabular}


Table IV. National Heritage Site compared 2018-1942.

\begin{tabular}{|c|c|}
\hline National Heritage Site & $\mathbf{1 9 4 2}$ Map \\
\hline Panopticon & Monument \\
\hline Alberto Castilla Music hall & Monument \\
\hline National building & Monument \\
\hline Saint Jorge Cloister & Important \\
\hline Picaleña Railroad Station & No \\
\hline
\end{tabular}

Table V. Number of main buildings per year in Bogotá based on the maps 1894-1933 according to (Cuéllar Sánchez \& Mejía Pavony 2007).

\begin{tabular}{|c|c|c|c|}
\hline Year & buildings & page & details \\
\hline 1894 & 285 & 49 & including commercial \\
\hline 1896 & 91 & 50 & Including squares \\
\hline 1905 & 39 & 53 & \\
\hline 1906 & 103 & 55 & 50 buildings 53 squares \\
\hline $1906-$ & 132 & 57 & \\
\hline 1908 & 51 & 63 & \\
\hline 1910 & 53 & 67 & 27 religious, 26 civic \\
\hline 1911 & 130 & 69 & \\
\hline 1913 & 122 & 70 & \\
\hline 1930 & 42 & 81 & \\
\hline 1932 & 36 & 83 & \\
\hline
\end{tabular}

\section{The technic}

Using aero photogrammetry with cartographic purposes started in the world around 1912-1920, as an exploratory process to identify technical imprecisions (Center for Photogrammetric Training 2008). Because of that, accurate innovations maturate the technic around 19361937 and mapping focus changes from military uses to civilian needs after the Second World
War, but national armies controlled the technic (Doyle 1964).

In Latin America, cartographic dependencies associated to the national armies started in XIX century. During the XX century, these cartographic dependencies became military geographic institutes. The main data of their creation are 1901 (1919) in Argentina (Instituto Geográfico Nacional de Argentina 2018), 1913 in Uruguay (Instituto Geográfico Militar de Uruguay 2017), 1932-1940 in Paraguay (Ministerio de Educación y Ciencias de Paraguay 2019), 1933-1944 in Peru (Instituto Geográfico Nacional del Perú 2019), 1922 in Chile (Instituto Geográfico Militar de Chile 2019), 1936 in Bolivia (Instituto Geográfico Militar Bolivia 2019), and 1947 in Ecuador (Narváez \& León 2016). Brazil, Panamá and Venezuela had not geographic military institutes but directions or institutes dependent of other ministries like the Public Works.

The implementation of the aero photogrammetry with cartographic purpose in Latin America started in 1918-1920 with the Austrian Mission for mapping the Brazilian territory and Federal District of Rio de Janeiro in 1922. After that, Sao Paulo was mapped in 1928-1930 by S.A.R.A, the Brazilian-Italian Society for the Aerophotogrammetry Survey (Società per Azioni Rilevamenti Aerofogerammetrici) (Carneiro da Silva 2012) settled in Rome and with great impact in mapping the central Italian landscapes (Ripa et al. 2013). The collection of these maps of Brazil is very detailed and show the most important buildings in brown. Although, the conventions have not the concept of monument [Figure 5].

In 1938, the Military Geographic Institute of Colombia elaborated an aero topographic map of Bogotá, to commemorate the fourth centenary of its foundation (Cuéllar Sánchez \& Mejía Pavony 2007, p. 94-95). The technic is the same of the Ibague map of 1942: the restitution 


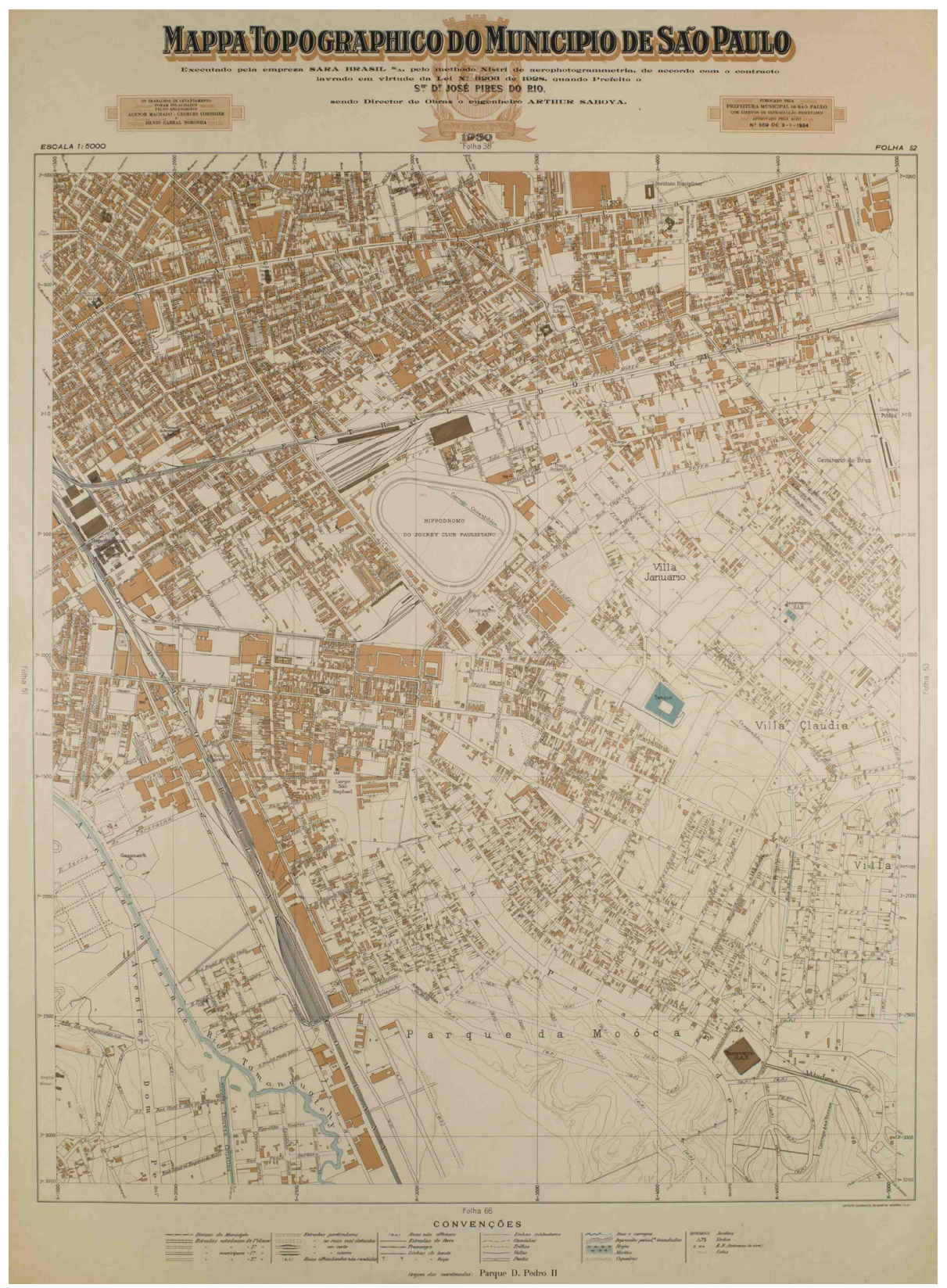

\author{
Figure 5. Map of São \\ Paulo based on aero \\ photogrammetry (1930). \\ Source: Museu Paulista. \\ Public domain/Museu \\ Paulista (USP) Collection.
}

of aerial views, elaborated by the Military and Cadastral Geographic Institute (Rozo 1952), and it is very probable that its purpose was the same: commemorate its foundation-day. The map of Bogotá 1938 has no conventions, but shows black filled shapes for some buildings, those are the monuments by interpolating data with the information of Ibague 1942 map. The number of monuments in the map of Bogotá 1938 is upper 36 shown in the older maps, which evidence more profound studies on the aspect of heritage in the city [Figure 6].

The technic of the map means that the criteria to judge the antiquity and architectural beauty, was determined by the national army, supported by local politics, public workers and the social elite. This aspect drives to understand the concepts of monuments in the map of 1942 as the primacy of the private over the public interest. 


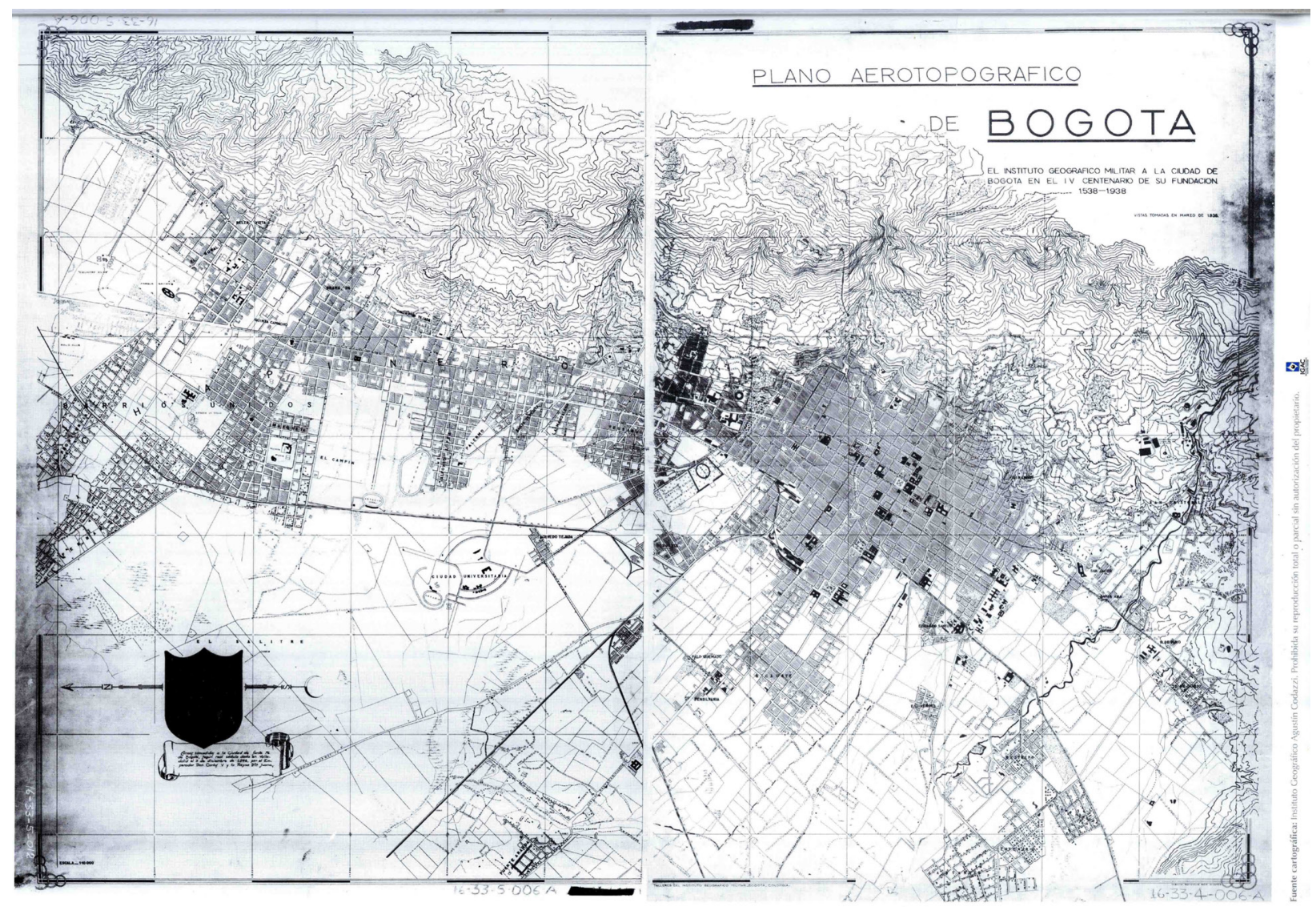

Figure 6. Aero topographic map of Bogotá. Military Geographic Institute (1938). Source: (Cuéllar Sánchez \& Mejía Pavony 2007, p. 95).

\section{What was the purpose of the map?}

There is a confluence of various aspects. The first one is the needing to create cadastral charts because of the conflict with Peru between 1932 and 1933. During that moment, the president Olaya Herrera delegated Alfonso López Pumarejo to negotiate a treaty of peace with Peru, intermediated by the League of Nations. López Pumarejo became president from 1934 to 1938 and 1942 to 1945.

In1934, López reorganized the General Military Staff (Estado Mayor General) or the personnel that are responsible for the administrative, operational and logistical needs, through the department of Topographic Surveying and the section of Aereophotogrammetry and Cartography (Presidency of the Republic 1934).
Because of that, the interest of mapping the Colombian territory marks the start of its government, the map of Bogotá in 1938 mark the end of his first presidency, and the map of Ibague in 1942 marks the beginning of his second presidential period.

In 1935, López signed the Roerich pact for the "protection of artistic and scientific institutions and historic monuments" (Nicholas Roerich Museum New York 2018). The transformation of the concept "main buildings" into "monuments" is a consequence of that movement to recognize the historical, artistic value for some architectural works. This concept means that the valuation of buildings as monuments, replaces the hierarchy of buildings as main in older plans.

This context of war fomented international associations, like the League of Nations to 
solve the Colombian-Peruvian War and the Pan American Union to protect monuments through the Roerich pact. At the same time, the map of Ibague represents the tensions of the World War Il those generated distrust towards the BrazilianItalian Society for the Aerophotogrammetry Survey (SARA) and the Colombian-German Air Transport Company (SCADTA: Sociedad Colombo Alemana de Transportes Aéreos), which took the aerial photographs, and represented a risk of becoming a Nazi allied. In response, U.S. created the Pan American-Grace Airways to compete and stop the expansion of the German capital based company. Therefore, U.S. and Colombian governments forced SCADTA to sell its assets and cease operations in 1940. The company took aerial photographs over Ibague in January 1940 and ceased operations in June of same year. In September, U.S. and Colombia agree a cooperation to portray strategic areas with Colombian aircrafts and American camera operators (George Davies 1984).

After that work of determining architectural monuments, the maps acquire other focus. In both cities, Bogotá and Ibague, the next charts determinate the perimeter for urban expansion and other criteria for intervene the city through ways, big buildings and fee simple models. Because of that, the aero photographic charts of Bogotá 1938 and Ibague 1942 show an important strategy of incorporating an international pact for protecting monuments in war moments, which derives in a cartographic instrument to guide urban decisions.

That background links directly the aero photography to the techniques of war and the forms of representation of the great colonial empires of the modern West, which translated their devices of power between them and the colonial world (Bourgeois \& Meganck 2003). Even, the genesis of the geopolitics of the civilizational process in the West, brings together pre-Colombian societies and the conquest, colonization and westernization of the Americas, an aspect evident in Latin America in the cosmopolitan nationalism (Martínez 2001). This concept of building an identity for nationstates mid-20th century, led to the trends to recover the past, through a romantic distorted relationtip with the pre-Columbian in a clearly western background (González Casas 2008).

\section{A political synthesis}

There are three important leaders in the background of the evolution of the concept of monument in the national laws and in the map of Ibague 1942. The presidents of the liberal party Enrique Olaya Herrera, Alfonso López Pumarejo and Eduardo Santos Montejo, members of a generation of political and intellectual leaders at the time of the first century after the independence war (Páramo Bonilla 2010).

They had relations that became tense by the time of the map. Olaya Herrera was president from 1930 to 1934, supported by López Pumarejo and Santos Montejo (Zapata Hincapié 2011). López Pumarejo negotiated a peace treaty with Peru during the presidency of Olaya Herrera (Toscano 2010). Olaya Herrera continued as minister of Foreign Affairs in 1935 during presidency of López Pumarejo. Santos Montejo was president from 1938 to 1942, preceded and succeeded by López Pumarejo. Santos Montejo was the director of the presidential campaign of Olaya Herrera and his minister of International Affairs during 1930, and representative to the League of Nations during the presidency of López Pumarejo (Herrera 2013). Santos Montejo became president of the Colombian Academy of History in 1945-1946 and consolidated his labour as the main person to direct the destiny of the protection of heritage (Niglio \& Rámirez Nieto 2016). 
They retook the power for the Liberal Party during 16 years, a period called the Liberal Republic, between 1930 and 1946. After that, started The Violence, a ten-year civil war from 1948 to 1958 , which leads to the social and architectural destruction (De Urbina González \& Zambrano Pantoja 2009). Consequently, the map of Ibague 1942 is also a plot of the political tensions in the middle of national and international wars, and the rising of the concept of monuments in the law but its destruction in the reality.

\section{What did happen in Ibague during 1940?}

The year 1940 is the key moment of the transformation of the city from de city beautiful movement, to the modern movement, because the city government bought lots for develop massive plans for working housing (Francel 2015b). That changed the goals of beautification fomented by the high class, for the development of working housing with no ornament and focused in function (Francel 2013). These principles were specified in the Urbanistic plan Future Ibague 1935 (Francel 2017b) and partially implemented from 1940 (Francel 2017d). Although polemic and unpopular (González Calle 2006), this plan generated basic criteria for monument valuation in a thematic line titled Aesthetics, very undefined, as follows:

It is preferable not to write anything about it [aesthetics] because in this field everything is very difficult to argue and because the considerations [on the decisions taken] would be literature full of common places, quotes from authors and other things pedantic and antipathetic. [And concludes that] the Old Ibague is delimited with enough precision" (Sociedad Industrial de Ingeniería y Construcciones (SIDEICO) S.A. 1935, p. 65).

In absence of later studies before 19401942, when the Military Geographical Institute took aerial photographs, the criteria of Ibague Future 1935 are the only one we have the base to interpret the 1942 Ibague map. That means that the architectural monuments, or valuable buildings, have imprecise criteria to judge, and become "literature of common places", "pedantic and antipathetic". Instead of theoretical or even legal arguments, the monuments are assigned to the old zone of the city, "delimited with enough precision", which evokes the concept of monument as the building that become relevant for its relation with the history, because there are not explicit delimitation of the old city, neither in words nor in graphics.

There are three important local events related to the map. The First data is that in 1938, the city government gave in a terrain to build an airdrome, but the construction of the airport was in 1946 as well as the first airline Saeta (Aeronautical Society of Tolima) (Concesionaria San Rafael S.A. 2014, p. 11-13). That means that the airport started functions 8 years after the cession of the terrains and the aero-photographers in 1940 hadn't an adequate place to land, but the local government establish an airdrome to solve the basic needing. Mapping the territory surpassed the infrastructural conditions of the city as the generation of criteria about the monuments.

The second event implies 1938 as a year for demographic census, with 27.448 inhabitants (Cámara de Comercio de Ibagué 1983, p. 33). That census implies the recognition of elements like the entire buildings that constitutes the city and, consequently, the delimitation of the urban perimeter, that tends to the soil control over the national territory. The information of this census was the base to contrast the aerial photographical data and take decisions to establish new taxes and place new public buildings. 
The third event in 1940, as the concretion of the last one, was the inauguration of Female Normal School, placed on the Street 29, the periphery of that time. It is black filled in the map, like a monument, and correspond to the moment that the national government introduced the cadastre as a tool to develop the country through the property identification in 1940 (Insituto Geográfico Agustín Codazzi 2019).

There emerges a consideration about the characteristics of the concept of monument, as an intentional commemorative-value as a part of the "modern cult of monuments" (Riegl
2001), but in its character of the new, loved by the masses, and "[...] defined its newness by its very coherence with the present, its oneness with the time" (Arrhenius 2003). That means that the government created a new building in order to be a monument and, because of that, incorporated it into the map draft in the same year of the building. In terms of the Law 5 of September 6 of 1940, the Female Normal School became a monument because of its architectural beauty [Figure 7].

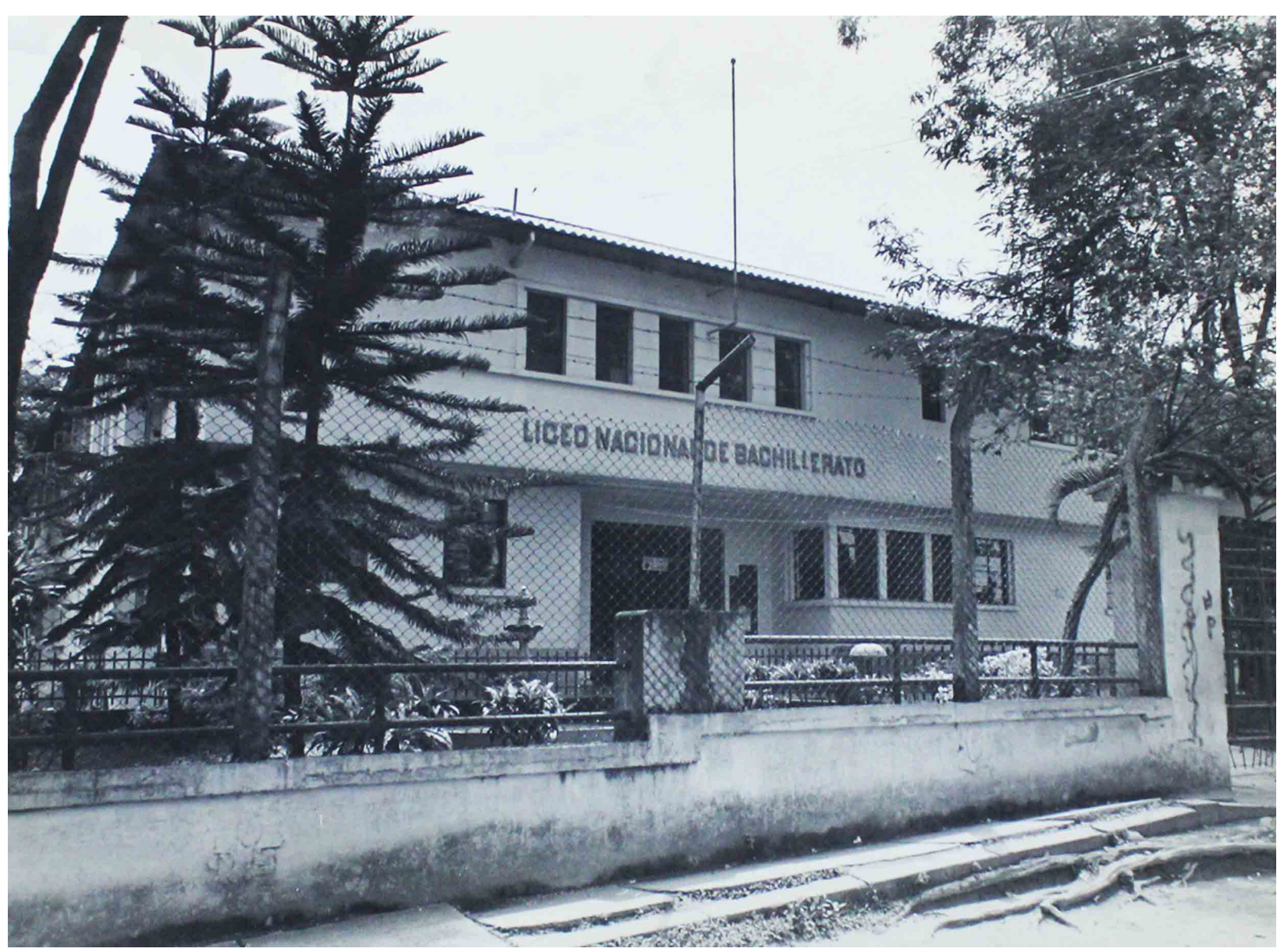

Figure 7. Female Normal School. Renamed National Lyceum in 1971. Photo by David Oviedo (1992). Source: Visual Memory File of Library Darío Echandía of Bank of Republic. Topographic number: 586. 


\section{CONCLUSIONS}

The concept of monument in Colombia applied to architecture up to 1940, have three components: public utility, antiquity, and architectural beauty. The public utility explains that the most of the monuments in the map are public buildings and, in a second level, educational or ludic private buildings that attends to the public use or utility. In this sense, this criterion is in the condition of a building to be useful for the population. Its level of restriction by private use distances the public interest.

The criteria of antiquity means that a building from an overcome period could be classified as a monument, which means that antiquity is a remote time and simultaneously a loss of validity of a way of doing architecture. Because of that, the first declared monuments come from the pre-Columbian and colonial periods and the buildings of the last period. That happens in the law of 1940, because this is a key moment for the introduction of modern architecture and the end of eclecticisms. The law of 1940 legitimates this change started in the middle of 1930's and the recent old buildings as the new ones, becomes deserve to be conserved as national heritage.

Even today, the concept of monument is undefined and controversial because of the interest of building companies and the hard way to argue the public interest. As we revised, these concepts depend on the established power. Nowadays, the building companies try to argue that the public interest violate the freedom in the national constitution. Therefore, the defence of heritage depends on the strength of the local government in relation to the power of the building companies. In the middle, the concept of monument is blowing in the laws and the maps, but always in danger.

\section{REFERENCES}

ALVAREZ M \& FRANCEL A. 2018. Historical patrimonial study and three-dimensional restitution of the Tolima soft drink factory (1945-2016). História (São Paulo) 37(1): 1-26. doi:http://dx.doi.org/10.1590/1980-436920180000000017.

ARRHENIUS T. 2003. The Fragile Monument: On Alois Riegl's Modern Cult of Monuments. NJAR 4: 51-55. Obtenido de http://arkitekturforskning.net/na/article/ viewFile/296/256.

BARBOSA J. 2012. El papel de la Academia Colombiana de Historia en la conservación del Patrimonio Cultural Inmueble. Ensayos. Historia y teoría del arte 23: 135-154. Obtenido de http://bdigital.unal.edu.co/44263/1/46176224276-1-SM.pdf.

BOURGEOIS I \& MEGANCK M. 2003. Aerial Photography and Archaeology 2003: A Century of Information. Ghent: Academia Press.

CÁMARA DE COMERCIO DE IBAGUÉ. 1983. Monografía del Municipio de Ibagué. Bogotá: DANE - Departamento Administrativo Nacional de Estadística. Obtenido de http://biblioteca.dane.gov.co/media/libros/ LD_5539_1983_EJ_5.PDF.

CARNEIRO DA SILVA D. 2012. Evolution of Photogrammetry in Brazil. Rev Bras Cartogr 64(6): 749-765.

CENTER FOR PHOTOGRAMMETRIC TRAINING. 2008. History of Photogrammetry. Center for Photogrammetric Training. Obtenido de http://ibis.geog.ubc.ca/courses/geog373/ lectures/Handouts/History_of_Photogrammetry.pdf.

CIFUENTES SEGOVIA MF. 2015. Retrospectiva constructiva e histórica del Panóptico de Ibagué, Colombia. Apuntes 28(2): 16-29. doi:http://dx.doi.org/10.11144/Javeriana. apc28-2.rchp.

CONCESIONARIA SAN RAFAEL S.A. 2014. Diagnostico Ambiental de Alternativas - DAA - Variante del Boquerón. Ibagué: Concesionaria San Rafael S.A. Obtenido de ftp://ftp.ani.gov.co/Iniciativas\%20Privadas/GICA/GICA/ Componente_Ambiental/Tramo\%202\%20DAA/VCB_\%20 DAA\%20CAP\%207\%20-\%20V1.pdf.

CONGRESS OF COLOMBIA. 1918. Law 48 of 1918 On the foment to Fine Arts. Bogotá: Diario Oficial. Año LIV. N. 16550. Obtenido de http://www.suin-juriscol.gov.co/ clp/contenidos.dll/Leyes/1602198?fn=document-frame. $\mathrm{htm} \$ \mathrm{f}=$ templates\$3.0.

CONGRESS OF COLOMBIA. 1931. The Law 103 of 1931, which promotes the conservation of the archaeological monuments of San Augustin. Bogotá: Diario Oficial 
número 21812. Obtenido de http://www.icanh.gov. co/?idcategoria=2095.

CONGRESS OF COLOMBIA. 1940. On national monuments and realization of some works in the city of Cartagena. Official Diary. Obtenido de http://www.suin-juriscol.gov. co/viewDocument.asp?id=1559922

CONGRESS OF THE STATES OF COLOMBIA. 1865. Law 18. Decree creating the National Institute of Sciences and Arts and allocating premises for its establishment. Bogotá, Colombia: Congress of the States of Colombia. Obtenido de https://en.unesco.org/sites/default/files/colombia_ ley_18_24_04_1865_spa_orof.pdf.

CUÉLLAR SÁNCHEZ M \& MEJÍA PAVONY G. 2007. Atlas histórico de Bogotá. Cartografía 1791-2007. Bogotá: Editorial Planeta Colombiana S.A.

DE URBINA GONZÁLEZ A \& ZAMBRANO PANTOJA F. 2009. The impact of "El Bogotazo" on residential activities and high level service-provision in Bogotá's historical center. A case study. dearq (5): 152-165. doi:https://doi. org/10.18389/dearq5.2009.15.

díAZ ÁNGEL S, MUÑOZ ARBELÁEZ S \& NIETO OLARTE M. 2010. Ensamblando la nación: Cartografía y política en la historia de Colombia. Bogotá D.C.: Universidad de Los Andes, Facultad de Arte y Humanidades, Facultad de Ciencias Sociales, Departamento de Historia, Centro de Estudios Socioculturales e Internacionales (CESO), Ediciones Uniandes. Obtenido de https://books.google.com.co/ books?id=M6A7DwAAQBAJ \&pg=PA23\&lpg=PA23\&dq=1601 +Mapa+del+r\%C3\%ADo+Magdalena+desde+su+desemb ocadura+hasta+m\%C3\%A1s+arriba+de+Mariquita\&sourc e=bl\&ots=DFl3u_Ov0V\&sig=M1WmlpNduMoOyjwwdie3p mF_USO\&hl=es\&sa=X\&ved=2ahUKEwjV2--1jITdAhXKu.

DOERING JG. 1983. Planos de Lima 1613-1983. Lima: Municipalidad de Lima Metropolitana - Petróleos del Perú. Obtenido de https://www.tdx.cat/bitstream/ handle/10803/1552/11.JHM_ANEXO_PLANOS. pdf? sequence $=12$ \&isAllowed $=y$.

DOYLE F. 1964. The Historical Development of Analytical Photogrammetry. Photogrammetric Engineering 30(2): 259-265. Obtenido de https://www.asprs.org/wpcontent/uploads/pers/1964journal/mar/1964_mar_259265.pdf.

EL NUEVO DÍA. 2019. They intend to overthrow decree that regulates construction around the $\mathrm{LSH}$. El Nuevo Día. Obtenido de http://m.elnuevodia.com.co/nuevodia/ tolima/ibague/430515-pretenden-tumbar-decreto-queregula-construccion-alrededor-de-los-bic-pal.
FRANCEL A. 2013. Cuatro décadas de arquitectura ibaguereña (1904-1940). Ibagué: Universidad de Ibagué.

FRANCEL A. 2015a. Herramientas gráficas para el estudio de la historia de la arquitectura historicista en Ibagué (1893-1940). Encuentro de Investigación en Diseño y Ciencias Humanas, p. 12-19. Ibagué: Corporación Unificada Nacional de Educación Superior. Obtenido de http://encuentroinvcunregionaltolima.blogspot.com. $\mathrm{col}$.

FRANCEL A. 2015b. Metodología y reflexiones para la reconstrucción de la historia urbana del barrio Belén de Ibagué (1921-1925). Simposio Colombiano de Historia Regional y Local HistoReLo V: 1-13. Ibagué: Universidad Nacional de Colombia.

FRANCEL A. 2015c. Tensiones ideológicas y materializaciones de una ciudad intermedia a comienzos del siglo XX. Paradigmas y repercusiones en la ciudad contemporánea. Ibagué, Colombia (1910-1935). Seminario Internacional de Investigación en Urbanismo VII: 1-18. Obtenido de http://upcommons.upc.edu/ bitstream/handle/2117/80271/72BCN_FrancelAndres. pdf?sequence $=1 \&$ isAllowed $=y$.

FRANCEL A. 2015d. The Main Commercial street in Ibagué (Colombia), 1893-1950. A study of its architectural and conceptual transformations that come from an industrial model from the Colonial period until the creation of the Republic and the first wave of Art Deco. Dearq 17: 56-73. doi:http://dx.doi.org/10.18389/dearq17.2015.04.

FRANCEL A. 2017a. Buildings that Passed and the Institution that Remain. The Government of Tolima (Colombia) between 1886 and 1957. HistoReLo, 9(17): 123151. doi:https://doi.org/10.15446/ historelo.v9n17.55567.

FRANCEL A. 2017b. El plan urbanístico Ibagué Futuro 1935. Ibagué, Tolima, Colombia: Universidad del Tolima. Obtenido de https://www.researchgate.net/ publication/323812143_El_Plan_Urbanistico_Ibague_ Futuro_1935.

FRANCEL A. 2017c. Historia y patrimonio de la periferia interior de Ibagué. Ibagué: Premio de investigación en patrimonio. Alcaldía de Ibagué. Caza de libros editories. Plan municipal de estímulos. Obtenido de https://www. academia.edu/35357626/Historia_y_patrimonio_de_la_ periferia_interior_de_lbagu\%C3\%A9.

FRANCEL A. 2017d. Overlapping historical cartography as a method of morphological analysis and taking planning decisions. Ibague, Colombia, 1935-2016. urbe, Rev Bras Gest Urbana 9(2): 1-21. doi:http://dx.doi.org/10.1590/21753369.009.002.a010. 
FRANCEL A \& OJEDA JA. 2016a. Reconstruction of the architectural history of the Salesian religious complex from power relations in Ibague, Colombia, 1904-1952. A\&U 36(1): 5-12. Obtenido de http://rau.cujae.edu.cu/ index.php/revistaau/article/view/353.

FRANCEL A \& OJEDA JA. 2016b. Salesian Eclectic Architecture as a Material Result of Republican Political Context in Ibague (Colombia), 1904. HistoReLo 8(15): 238-269. doi:http://dx.doi.org/10.15446/historelo.v8n15.47480.

FRANCEL A \& OJEDA JA. 2016c. Archaeology of architecture at the Palace of Justice in Ibague, Colombia, 2015-1918. A\&U 36(2): 5-21. Obtenido de http://rau.cujae.edu.cu/ index.php/revistaau/article/view/364.

FRANCEL A \& OJEDA JA. 2016d. Conceptual and stylistic architecture interactions in the Republican period. Ibagué, Colombia, 1893-1945. A\&U 37(3): 1-19. Recuperado el 15 de enero de 2016, de http://rau.cujae.edu.cu/index. php/revistaau/article/view/379.

GEORGE DAVIES RE. 1984. Airlines of Latin America. Washington, D.C.: Smithsonian Institution Press.

GIRARDI G. 2009. Mapas desejantes: uma agenda para a Cartografia Geográfica. Pro-Posições 20(3). doi:http:// dx.doi.org/10.1590/S0103-73072009000300010.

GONZÁLEZ CALLE JL. 2006. De la ciudad al territorio. La configuración del espacio urbano en Ibagué 1886-1986. Ibagué: Aquelarre.

GONZÁLEZ CASAS LL. 2008. Tiempos superpuestos: arquitectura moderna e "indigenismo" en obras emblemáticas de la Caracas de 1950. Apuntes 21(2): 266-279.

HERRERA ÓF. 2013. Colombia, the paradigm of political transformation from 1930 to 1946. Rev Colomb Soc 4(2): 336-347. Obtenido de https://dialnet.unirioja.es/servlet/ articulo?codigo $=5123779$.

INSITUTO GEOGRÁFICO AGUSTín CODAZZI. 2019. 80 hechos que marcaron la historia del IGAC. Obtenido de https:// igac.gov.co/es/contenido/80-hechos-que-marcaron-lahistoria-del-igac.

INSTITUTO GEOGRÁFICO MILITAR BOLIVIA. 2019. Instituto Geográfico Militar. Obtenido de Historia: http://www. igmbolivia.gob.bo/i_historia.php.

INSTITUTO GEOGRÁFICO MILITAR DE CHILE. 2019. Instituto Geográfico Militar. Obtenido de Inicios del Instituto Geográfico Militar: https://www.igm.cl/index.php\#*.

INSTITUTO GEOGRÁFICO MILITAR DE URUGUAY. 2017. Instituto Geográfico Militar. Obtenido de Historia: http://www.igm. gub.uy/historia/.
INSTITUTO GEOGRÁFICO NACIONAL DE ARGENTINA. 2018. Instituto Geográfico Nacional. Obtenido de Algo de nuestra historia: http://www.ign.gob.ar/ Arealnstitucional/AlgoDeHistoria.

INSTITUTO GEOGRÁFICO NACIONAL DEL PERÚ. 2019. Reseña Histórica. Recuperado el 06 de 02 de 2019, de https:// www.ign.gob.pe/resena-historica/.

MARTÍNEZ F. 2001. El nacionalismo cosmopolita. La referencia europea en la construcción nacional en Colombia, 1845-1900. Bogotá: Banco de la RepúblicaInstituto Francés de Estudios Andinos.

MINISTERIO DE EDUCACIÓN Y CIENCIAS DE PARAGUAY. 2019. Ministerio de Educación y Ciencias. Obtenido de Día del Instituto Geográfico Militar: https://www.mec.gov.py/cms_v2/ recursos/6534-dia-del-instituto-geografico-militar.

MORENO MARTín FJ. 2014. Arqueología de la Arquitectura. Una visión conciliadora desde la Historia del Arte. Arqueología de la Arquitectura 11: 1-19. doi:http://dx.doi. org/10.3989/arq.arqt.2014.008.

NARVÁEZ R \& LEÓN FR. 2016. 87 años de generación cartográfica en el Ecuador, información y comunicación. Simposio Iberoamericano de Historia de la Cartografía VI: 1-8. Obtenido de https://www.researchgate.net/ publication/303376420_87_anos_de_Generacion_ Cartografica_en_el_Ecuador_Informacion_y_ Comunicacion.

NICHOLAS ROERICH MUSEUM NEW YORK. 2018. Roerich Pact and Banner Of Peace. Protection of artistic and Scientific institutions and historic monuments (Inter-American). Washington: Pan American Union. Obtenido de http:// www.roerich.org/roerich-pact.php.

NIGLIO O \& RÁMIREZ NIETO JV. 2016. Historia, patrimonio e investigación científica. Inquietudes de Angiolo Mazzoni del Grande, arquitecto italiano en la Universidad Nacional de Colombia(1948-1950). Una experiencia de investigación internacional. Simposio de Investigación en Arquitectura III: 171-178. Obtenido de https://s3.amazonaws.com/ academia.edu.documents/35574555/MAZZONI_UNAL_ Niglio_Ramirez.pdf?AWSAccessKeyId=AKIAIWOWYYGZ 2Y53UL3A\&Expires $=1554314631 \&$ Signature $=u 8 n p K \% 2 F$ YvDhEqvWuuQZh9Cw9H8bg\%3D\&response-contentdisposition=inline\%3B\%20filename\%3DHistoria_ Patrimo.

PÁRAMO BONILLA CG. 2010. Decadencia y redención. Racismo, fascismo y los orígenes de la antropología colombiana. Antípoda. Revista de Antropología y Arqueología 11: 67-99. Obtenido de https://revistas. uniandes.edu.co/doi/abs/10.7440/antipoda11.2010.06. 
PRESIDENCY OF THE REPUBLIC. 1934. Decree 1689 1934. By which the General Staff is reorganized. Bogotá. Obtenido de http://www.suin-juriscol.gov.co/viewDocument. asp?id=1332060.

RATAJSKI L. 1977. The research structure of theoretical cartography. Cartographica: The International Journal for Geographic Information and Geovisualization 14(1): 46-57. Obtenido de http://www.utpjournals.press/doi/ abs/10.3138/P2Q9-616W-0444-0Q34

RIEGL A. 2001. Le culte moderne des monuments. Sa nature, son origine. Socio-Anthropologie 9. https:// journals.openedition.org/socio-anthropologie/5.

RIPA MN ET AL. 2013. Evolution of some Mediterranean landscapes of Central Italyfrom historical aerial photographs. J Agric Eng 44(2s): 483-489. doi:https:// doi. org/10.4081/jae.2013.338.

ROZO D. 1952. Historia de la cartografía de Colombia. Boletín de la Sociedad Geográfica de Colombia 4(X): 1-13. Obtenido de https://sogeocol.edu.co/ documentos/010_04_Hist_de_cart_de_col.pdf.

SCHIMALSKI MB. 2001. Monorestituição: uma metodologia para geração rápida de mapeamento urbano digital a baixo custo. Curitiba, Brasil: Universidad do Paraná. Dissertação apresentada como requisito parcial à obtenção do grau de Mestre em Ciências Geodésicas, Curso de Pós-Graduação em Ciências Geodésicas, Setor de Ciências da Terra. Obtenido de https://acervodigital. ufpr.br/handle/1884/43777.

SOCIEDAD COLOMBIANA DE ARQUITECTOS - REGIONAL TOLIMA. 2002. Estudio TEURA. Taller del Espacio Urbano, Restauración y Arquitectura 1994-1996.

SOCIEDAD INDUSTRIAL DE INGENIERÍA Y CONSTRUCCIONES (SIDEICO) S.A. 1935. Informe sobre el plano de Ibagué, levantado en catálogo de arrendatarios de ejidos, áreas de lotes, etc,. Ibagué: Honorable Concejo Municipal de Ibagué.

TOSCANO Óm. 2010. Los dos gobiernos de Alfonso López Pumarejo: estado y reformas económicas y sociales en Colombia (1934-1938, 1942-1945). Apuntes del CENES 29(50): 151-171. doi:https://doi.org/10.19053/01203053.v29. n50.2010.49.

UNESCO. 2019. Port, Fortresses and Group of Monuments, Cartagena. Obtenido de Unesco World Heritage Centre 1992-2019: https://whc.unesco.org/en/list/285.

ZAPATA HINCAPIÉ OJ. 2011. Atraer el pueblo a las urnas: la campaña electoral de Enrique Olaya Herrera. HiSTOReLo 3(6): 193-230. doi:https://doi.org/10.15446/ historelo. v3n6.20193.

\section{How to cite}

FRANCEL-DELGADO AE \& URIBE-KAFFURE C. 2021. The concept of monument in the map of 1942. Ibagué, Colombia. An Acad Bras Cienc 93: e20191454. DOI 10.1590/0001-3765202120191454.

Manuscript received on November 25, 2019;

accepted for publication on April 22, 2020

\section{ANDRÉS E. FRANCEL-DELGADO}

https://orcid.org/0000-0002-3249-3191

\section{CLAUDIA URIBE-KAFFURE}

https://orcid.org/0000-0001-8191-2615

Universidad del Tolima, Facultad de Tecnologías, Campus de Santa Helena, Cl 42 1-02, Ibagué, Tolima, Colombia

Correspondence to: Andrés Ernesto Francel-Delgado

E-mail: aefranceld@ut.edu.co

\section{Author contributions}

Andrés Francel designed the study. All authors contributed to the analysis and the paper writing.

\section{(cc) BY}

